\title{
USING SERVICE LEARNING TO ASSESS TOURISM DESTINATION IMAGE: A FOCUS ON RIO DE JANEIRO
}

\author{
CLAUDIA G. GREEN \\ Pace University, Lubin School of Business, USA
}

\begin{abstract}
This research profiles public perception of the favelas of Rio de Janeiro after hosting the 2014 World Cup and before the 2016 Olympics. The International Olympic Committee's mission is that the Olympics be truly sustainable - socially, environmentally and economically. Rio was challenged to reduce crime in the favelas, improve waste management, expand and improve infrastructure, and build Olympic venues that would have a legacy for the community. The outcome was the construction of over 32 Olympic venues, 70 new hotels, and a transportation network with new roads, an enhanced rail network and modernized international airport. Thousands of jobs were provided including employment for people from the favelas. Media specialists converged upon Rio to give global coverage of the Olympic Games. Potential US based tourists were interviewed about their knowledge and perceptions of Rio de Janeiro as a tourism destination and, specifically, of the favelas. A random sample of 250 people were interviewed in 2014 after the 2014 World Cup and before the 2016 Olympics. Teams of university students enrolled in a tourism management course conducted the interviews as their service learning class assignment. Through this hands-on assignment, students: 1) gained personal insight into the social issues existing in the favelas; 2) applied their communication and critical thinking skills in interviewing people; and 3) developed an understanding of social issues as they relate to sustainable tourism development. This project was a collaboration between a US university and a Brazilian nonprofit organization that has the mission of improving the quality of life for Rio de Janeiro residents through empowering informal and formal communities. The survey instrument consisted of 28 quantitative and qualitative questions. Regardless of the media coverage, public perception was not significantly altered. This research highlights the challenges in changing potential tourists' perceptions of selected tourism destinations and the opportunity for student service learning projects.
\end{abstract}

Keywords: Olympics, Rio de Janeiro, sustainable, favelas, perception, service learning.

\section{INTRODUCTION}

Rio de Janeiro is known as one of the most exotic and iconic tourism destinations of the world because of its dramatic location on the coast in the Brazilian Atlantic Rainforest. The golden age of travel to Rio de Janeiro was from the early 1920s to 1950 s when international celebrities and high society came to stay in the grand hotels of the period such as the Gloria Hotel (1922) and the Copacabana Palace (1924). Rio was an intriguing, romantic destination with casinos and live performances in local nightclubs. However, Rio has not always been one of the most desirable destinations in the world [1].

In 1960 the capital of Brazil was moved from Rio to Brasilia. During this period, modernization destroyed some of the historic buildings of Rio and skyscrapers were built in their places. Simultaneously, shanty towns (favelas) grew in size and number due to mass immigration of people from the rural northeast of Brazil who were looking for employment in Rio. At the same time, there was an increase in crime and violence [2]. Tourism to Rio declined during the military dictatorship period between 1964 to 1985. Unrest prevailed in the city and the military regime retaliated by withholding funds that would have been used to maintain the city's infrastructure. As a result, the city went into further decline.

It was not until 1992 when Rio was selected as the site for the United Nation's Conference on Environment and Development that the federal government spent about $\$ 1$ billion dollars on the city infrastructure. In 2007 and 2009 when Brazil received the bid for two mega sports 
events - the 2014 World Cup and 2016 Olympics, consecutively, the world's attention became focused on Rio. The authorities realized they needed to deal not only with the infrastructure, but also the image and reputation as being a destination with a high crime rate. Crime is particularly high in the numerous favelas where 1.5 million people or $22 \%$ of the population live in Rio [2].

Beginning in the 1970s, many non-government organizations (NGOs) stepped in to address some of the social problems prevalent in Rio. Today there are 338,000 NGOs addressing a variety of social issues [3]. The mission of many of these NGOs is to give a voice to the people living in the favelas and to assure that there is more equity in the availability of health care and education. One of these NGOs conducts surveys to gather data on public sentiment that often has an impact on policy decisions about the favelas in Rio.

In 2014, university students in New York City were invited to participate as volunteers in a service learning project where they would interview people about their perceptions of the favelas of Rio following the 2014 World Cup and preceding the 2016 Olympics.

The purpose of this research is twofold: 1) to assess public opinion regarding Rio's favelas; and 2) to assess the effectiveness of a university service learning project in teaching students about global social issues. The goal of this service learning project was to give students a hands-on experience where they would learn about the impact of poverty on destination image and tourism. This project was a collaboration between university students/faculty and a Brazilian NGO.

\section{LITERATURE REVIEW}

\subsection{History of the favelas of Rio de Janeiro}

Favelas are often inappropriately described as Brazilian slums with squalor, substandard housing and residents who are land squatters and have no legal property rights. Favelas are typically located in or close to urban areas. A more accurate definition of a favela according to [2] is "squatter settlements where people occupied the land illegally due to the lack of access to affordable public housing in the late 19th and early 20th century". The Instituto Brasileiro de Geografia e Estatistical reported that in 2010, 22\% of the 6,323,037 residents of Rio lived in favelas. These 1,393,314 people live in the 763 favelas in Rio. These statistics reflects an increase of $18.7 \%$ from 2000 [4].

These settlements are not always built with scrap materials such as cardboard boxes, corrugated metal and sheets of plastic. As a matter of fact, numerous homes in the favela are built of brick, concrete and reinforced steel. Many of the favela residents are employed as construction workers, domestics, cashiers, bus drivers and restaurant/hotel workers [5]. Even when some favela residents become more financially sustainable, they refrain from moving away from the favela because of the family ties and the sense of community that they have experienced while living there.

Typically, Brazil's favelas have been plagued by armed gangs and drug traffickers. One may wonder why there are gangs and drug traffickers in the favela. Over the years, gangs, often called a "shadow government", developed a social contract with the favela inhabitants in that they provided electricity, organized block parties, repaired roads and gave food to hungry families. In addition to dealing drugs and organizing prostitution rings, the gangs provided basic services not being supplied by the government. Historically, gambling was the first organized crime in Rio's favelas. Favela residents developed a type of loyalty to the gangs who used the funds generated from gambling to protect and provide jobs for the favela residents. During the 1980s when the cocaine market expanded, the gangs started dealing 
cocaine. In the favelas, gangs were the police force and they did not let crime happen unless it was their crime [6].

When Rio was awarded the opportunity to host two major global sports events, 2014 World Cup and 2016 Olympics, it was clear that the issues of both infrastructure and crime needed to be addressed. Through an alliance between federal, state and municipal governments, a set of strategic policies called the Police Pacification Unit (UPP) was developed to rid the favelas of crime [7]. Through the UPP process, police entered and occupied the favelas for indefinite periods in an attempt to drive out the drug gangs. The UPP started as a pilot project in Santa Marta favela and has spread to over 36 other favelas. Most of the focus has been on favelas close to the planned sport events venues and wealthier neighborhoods. Of the estimated 1000 favelas in greater Rio, almost all of the UPP occupied favelas are in or adjacent to the wealthiest neighborhoods such as Zona Sul (South Zone). Prior to the 2014 World Cup, the UPP occupied 40 favelas. The goal was to have 100 favelas UPP occupied before the 2016 Olympics. There has been a decrease in lethal crime since and a simultaneous increase in reported non-lethal crime since 2008 [8]. It is believed the increase in non-lethal crime is due to the fact that residents feel more comfortable in reporting these crimes as there is an increased police presence in selected favelas.

Tourists' demand for authenticity outside the standardized tourism experience is an example of the commodification of poverty. As long ago as the 19th century, visiting the slums or "slumming" became a tourism experience available mainly in the slums of London and Manhattan when upper class Londoners set out for the "undiscovered land of the poor" in the East End [9]. Today tours to poor, degraded urban areas have become increasingly popular in the favelas of Rio de Janeiro as well as other destinations such as India, Kenya, Indonesia and Detroit. These tours are now called "slum tourism" or "ghetto tourism" [10]. Two forms of tourism can be found in the favelas: 1) tours that are organized by members of the favela community to accept and host tours; and 2) those tours that have no direct link to the favela community. In her study of tourism in the favelas, Rezende [11] found that most of the tourism activity in Rio was in the southern sector with almost no tourism in the slums of the Northern Zone (the Baixada Fluminense region). She suggested that the proliferation of tourism in the southern sector is a function of the fact that favela dwellers in that area have a much more spectacular view of the skyline and beaches.

Previous studies on perceptions of the favela show that $81 \%$ of people who have a negative perception of favelas get most of their information about the favelas through mainstream news sources and films. Only $18 \%$ of those having positive views of the favelas learned of them via mainstream news sources. Thirty percent $(30 \%)$ of people who have positive impressions of the favelas developed these by traveling to Rio and being introduced through non-government organizations or other channels [2].

\subsection{Tourism destination image and the favelas}

Prior to 2002, there was a lack of academic research on tourism as an economic activity in Brazil. However, in 2014 in the Journal of Vacation Marketing, Rezende [11] reported that US citizens were an important and highly attractive market for Brazil tourism. They found that most Americans knew little about the country, however, they were motivated to travel there due to the perceived reputation of the country as being exotic and having natural attractions. The average stay of an American tourist is 11.8 days which make them a valuable tourism market.

Because destination image is an important factor in the decision to visit a particular destination, the concept of destination image began to be examined as long ago as the 1970s. 
Baloglu and McCleary [12] developed a path model which identified that information sources, number of sources, age, education and motivation to travel were contributors to the overall destination image. Crompton [13] identified that image is a function of the person's impressions, ideas, and beliefs of the destination. Gartner [14] and Echtner and Ritchie [15] said that image is a blend of a person's intellectual perception as well as their feelings about the destination. The behavior or action of the person is based on their intellectual feelings and perceptions. In 2007 Tasci et al. [16] investigated how destinations conceptualize and operationalize their image since the early 1990s. Media reports and casual conversation are also two factors that have an impact on the perceptions [14].

Based on a series of structured attribute scales and unstructured (open ended) questions, Rezende-Parker et al. [9] conducted a factor analysis on the image of Brazil as a tourism destination. They found visitors had a significantly more positive image of all aspects of Brazil than non-visitors. The positive images of Brazil included: many interesting destinations to visit, natural parks, abundant wildlife, beautiful beaches, variety of music and dance, scenic beauty, friendly people, nightlife, adventure and cultural opportunities. On the other hand, negative images included: poor security, lack of public transportation, crowded cities, lack of cleanliness and hygiene, beggars and language barriers. King et al. [17] examined the decay of a destination's image following a major sports event. Using an attitude survey of attendees, they found that destination image decayed over time. They also noted that the pattern of image decay was a function of the tourist's psychological connection to the destination.

Catalytic Communities is a non-profit organization in Rio that is charged with "representing, supporting and empowering residents of informal settlements, evolving strategically to support their needs as they arise". In December 2016, Catalytic Communities reported the results of their longitudinal study of media related to the Olympics. Their study began in 2008, one year before Rio was awarded the Olympic bid, through August 2016. During that period of time, they reported there were 1094 articles in the eight major global outlets which included the following: New York Times, Wall Street Journal, USA Today, The Guardian, The Daily Mail, The Telegraph, Associated Press and Al Jazeera. During this period, the favelas received "unprecedented levels of attention" as the number of articles increased seven-fold between 2008 and 2016. The primary term used to describe the communities was "slum" and "shanty towns". Approximately $45 \%$ of the articles gave negative portrayals of the favelas, $44 \%$ were neutral and only $7 \%$ were positive [18].

\subsection{Service learning in universities}

This research was conducted as part of a service learning course in a business school curriculum. Service learning in management education has evolved over the last 20 years. In the early beginnings, the Journal of Business Ethics Special Issue (1996) explored service learning as a benchmark by evaluating nine service learning projects to determine the strengths and opportunities for business education. By 2008, we were examining how to design sustainable partnerships between the university and local communities. Academic journals such as Michigan Journal of Community Service Learning have doubled the frequency of their journal publication because of the increased interest and demand for research in the area [19].

Service learning is defined as a strategy for teaching and learning that integrates community service with instruction and reflection. More specifically, it is "a pedagogical process where by students participate in a course-relevant community service to enhance their learning experience. All service learning experiences involved an integration of course 
material with volunteer service and some form of reflection on or reporting of outcomes" [20]. This process serves to enhance the student learning experience, teach civic responsibility, and improve communities [21]. Common in-service learning projects are learning experiences tied to the course; service to a non-profit agency or for-profit organization; and student reflections that connects the service and learning together [22].

In the process of making attempts to introduce service learning into higher education, Kolenko et al. [23] identified three aspects of service learning as: 1) personal insight; 2) application of skills; and 3) understanding social issues. The increasing number of empirical articles exploring service learning has demonstrated its potential effectiveness in: 1) developing students' commitment to service; 2) preparing students for careers; 3) contributing to their growth, self-esteem, improved communication skills and increased social awareness [22], [24]. Service learning is becoming a more common approach to university courses and is supported by the Campus Compact website [25] that features service learning syllabi in various disciplinary areas.

As a service learning assignment, this research will evaluate 1) public perceptions of the favelas following the press exposure after the 2014 World Cup and prior to the 2016 Olympics; and 2) students' personal insight, application of skills and understanding social issues.

\section{METHODS}

University students in New York City who were enrolled in a tourism management course with a service learning component participated in a global survey wherein they interviewed people to determine their perceptions of Rio de Janeiro favelas following the 2014 World Cup and prior to the 2016 Olympics. Students collected 250 surveys at major hub subway stations in New York City. The purpose of this research was not only to learn about perceptions of the favelas, but also to assess student perceptions of working on this service learning project as a tool for learning more about social issues and tourism development. This project occurred in October 2014 approximately three months after the completion of the 2014 World Cup.

The survey instrument was developed, tested and provided to the students by a Brazilian non-governmental organization. The survey included both quantitative and qualitative questions regarding respondents' opinions, image, and knowledge of the issues associated with the favelas in Rio. Students were given a thorough training in interviewing skills and data collection as well as tips on how to approach potential respondents. Ten teams of three students each were assigned survey time periods during peak traffic hours at Grand Central Station, Penn Station, Union Station and Wall Street Station. Each team was responsible for collecting a total of 25 surveys. Two hundred and fifty people were surveyed. The results, conclusions and recommendation will be reported in two sections: 1) results of the public perceptions of the Rio favelas; and 2) students' perceptions of the service learning project.

\section{RESULTS OF PERCEPTIONS SURVEY}

\subsection{Public perceptions of the Rio favelas demographics}

Of the people responding to the survey, 75.2\% $(\mathrm{n}=188)$ had a Bachelor degree or higher. The most common ethnicity was Caucasian $(40.7 \%, \mathrm{n}=94)$, followed by Asian/Pacific Islander $(25.5 \%, \mathrm{n}=59)$, Hispanic/Latino $(19.9 \%, \mathrm{n}=46)$ and African American $(7.8 \%, \mathrm{n}=$ 18). Most of the respondents lived in the city $(61.5 \%, \mathrm{n}=150)$. The bulk of the respondents to this survey could be considered millennials $(36.4 \%, \mathrm{n}=91)$ followed by Generation $\mathrm{X}$ 
$(23.6 \%, n=59)$. Most of the respondents were either students or employed in the field of management (Fig. 1).

\subsection{Knowledge of and travel to a favela}

Virtually all of the 250 people surveyed had heard of the term "favela" $(96.4 \%, \mathrm{n}=241)$ with no significant difference between the females and males. When asked about when they learned about the favelas, $71.3 \%(\mathrm{n}=170)$ said they learned about favelas before the 2014 World Cup with only $23.1 \%(\mathrm{n}=56)$ learning about the favelas during the coverage of the games (Fig. 2). More than one third respondents $(37.6 \%, n=94)$ had actually travelled to Rio de Janeiro.

$52 \%(n=49)$ of the people who travelled to Rio ended up visiting a favela. The numbers of people who visit the favelas has increased over the past four years. Most of the visits to the Rio favelas were spontaneous independent visits $(66 \%, \mathrm{n}=34)$ whereas $22.7 \%(\mathrm{n}=11)$ took organized tours offered by various tour companies (Fig. 3).

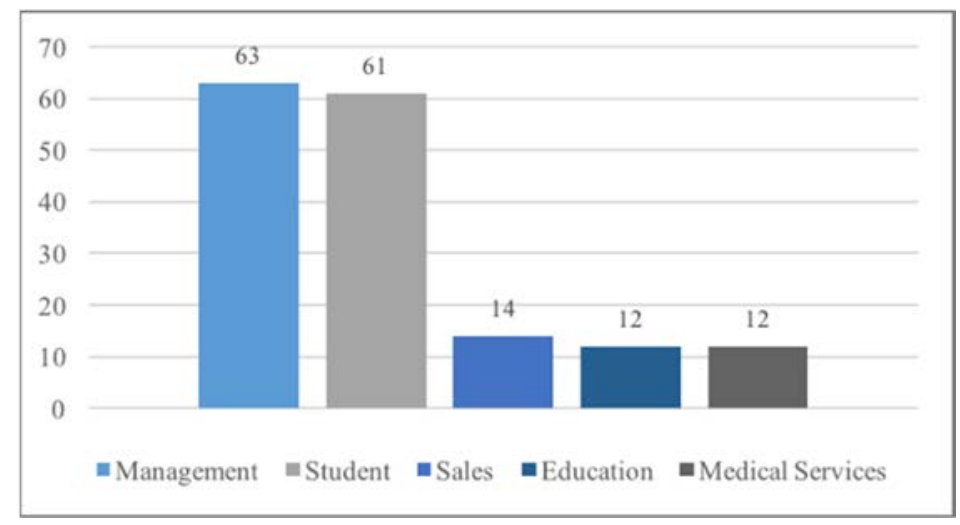

Figure 1: Professions of the respondents.

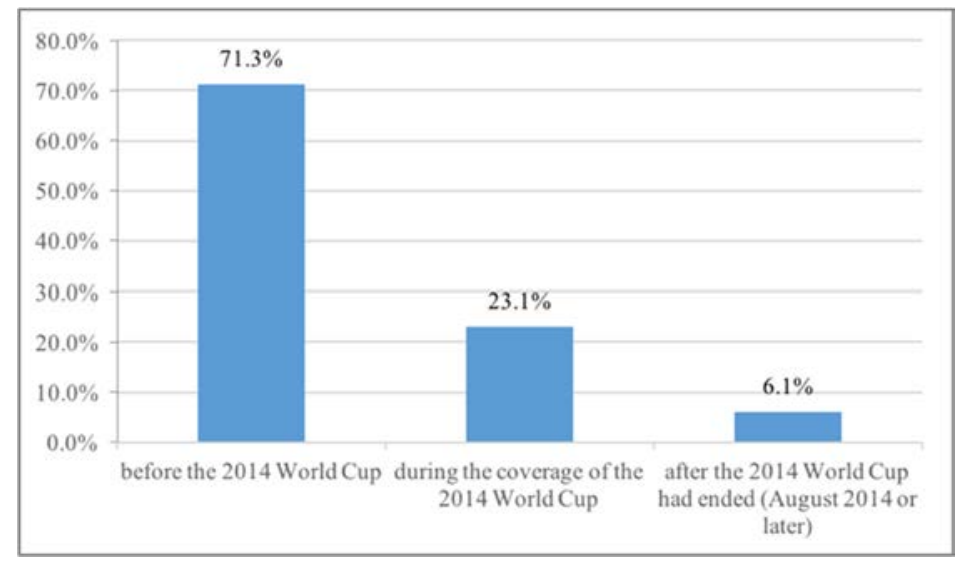

Figure 2: When did you first hear about favelas? 


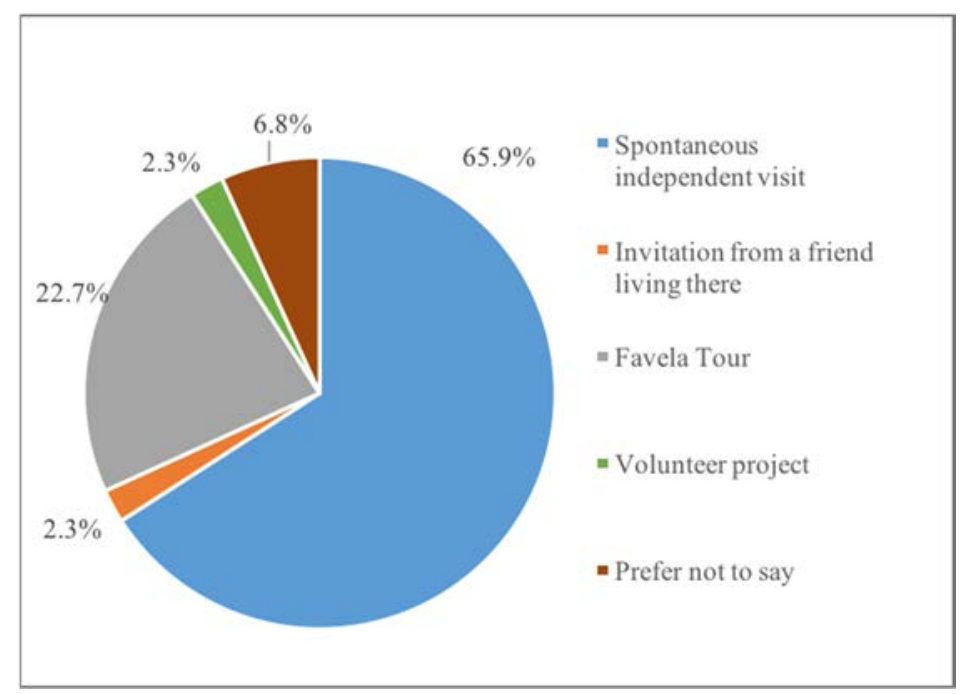

Figure 3: When did you go to favela in Rio?

Of those who visited the favelas, few could remember the specific name of the favela visited. About half $(52 \%, n=25 / 49)$ knew if the favela they visited was pacified or not. Of those people who had been to a favela $75.2 \%(\mathrm{n}=37 / 49)$ said that the experience did not change their views while only $24.1 \%(n=12 / 49)$ said their views became more positive. $60 \%$ $(n=150)$ of the respondents ranked their current views of the favelas as unfavorable views of favelas.

Most people learned about the favelas from mainstream news sources/networks $(54.3 \%$, $\mathrm{n}=114$ ). The next most common way they learned about favelas was through travel to Brazil $(14.8 \%, \mathrm{n}=28)$ and through films/movies $(13.3 \%, \mathrm{n}=28)$. The most commonly mentioned movies were "City of God" and "Fast and Furious". Very few learned about the favelas through work/research, alternative news sources, advocacy groups such as non-profit organizations and charities. Fig. 4 shows the type of mainstream new sources that provide information to the public about favelas with $\mathrm{CNN}$ being a primary source.

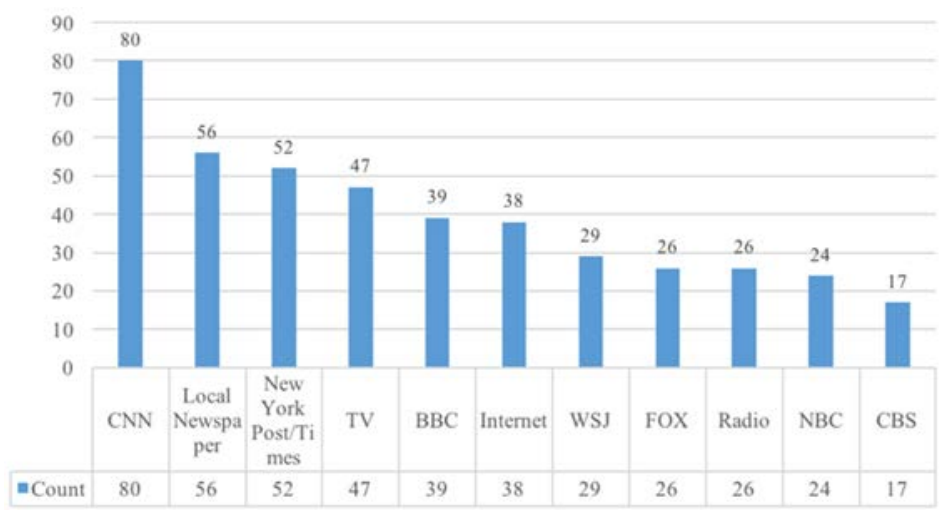

Figure 4: Mainstream new sources cited as a way to learn about favelas. 


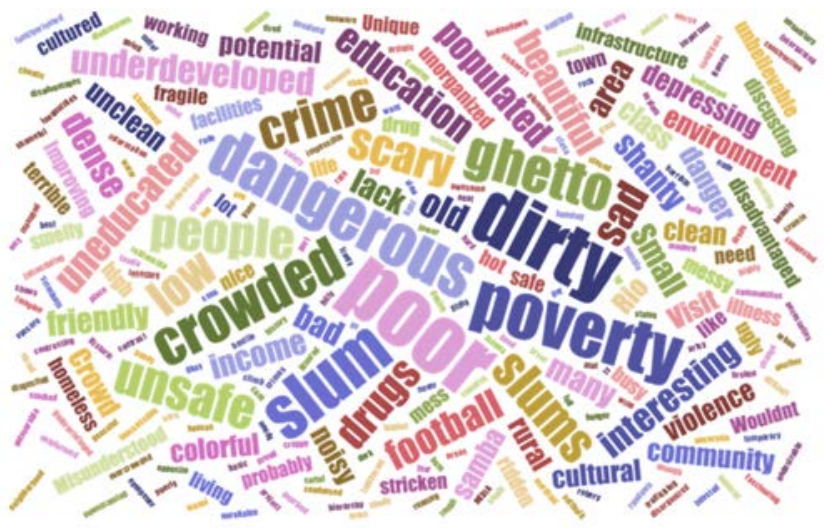

Figure 5: Word cloud that describes the Rio favelas according to survey sample.

The respondents were asked to describe the Rio favelas in a few words. Their responses were compiled in a word picture which depicts the most commonly stated descriptors in larger size text and the small size text as the less common descriptors. The primary descriptors, dirty, poor, ghetto, slum, poverty dangerous, and crime, were all negative in conation.

\subsection{Interest in learning more about the favelas}

Only $29.4 \%(n=64)$ were interested in learning more about favelas. Most respondents were not interested in learning more about Rio's favelas (70.3\%). This fact supports RezendeParker et al. [9] research on visitor's (particularly US visitor's) lack of knowledge about Brazil.

\section{CONCLUSIONS OF PUBLIC PERCEPTIONS OF FAVELA SURVEY}

The survey results indicate that regardless of the efforts taken by the federal, state and local government in Brazil, the favelas of Rio still present a negative image to the public which can, in turn, impact perceptions of the city and desire to travel there. The respondents in this study were educated, ethnically diverse and were represented by a high percentage of students and managers. Of those who travelled to Rio, half of them ended up visiting a favela for one reason or another, but they were unaware of the level of pacification of the favela that they visited. Of those visiting the favelas, most said that their visit did not change their initial unfavourable views. Most respondents knew about the favelas before the global coverage of the 2014 World Cup. The most common way that the respondents learned about the favelas was through mainstream media and film/movies which has also been demonstrated in past research [2].

Overall, the descriptors of the favelas continue to be negative as demonstrated by the word cloud featuring terms that respondents suggested about the favelas such as scary, dirty, crime, poverty, and dangerous. These descriptors are similar with those identified by RezendeParker et al. [9] who conducted a factor analysis of the negative images on Brazil as a destination such as lack of security, lack of public transportation, crowded cities, lack of cleanliness and hygiene, beggars and language barriers. Our results also show that people who have visited the favelas were not more likely to have a positive opinion of them which is inconsistent with the findings of Williamson [2]. 
Most of the information people know about the favelas is gathered from mainstream news media. A second source is movie/film, both of which often focus on the crime in favelas. Interest in slum tourism visits to the favelas is on the rise. However, few respondents were interested in learning more about the favela. Rezende-Parker et al. [9] found that Americans knew little about Brazil and our study showed they were not really interested in learning more.

\section{RECOMMENDATIONS OF PUBLIC PERCEPTIONS OF FAVELA SURVEY}

Because the image of Rio favelas is so negative, efforts to promote positive news through mainstream media is suggested. Less emphasis on crime and drugs in Brazilian film would also contribute to a better image of the Rio favelas. Filmmakers could focus on the more positive aspects of Rio. To improve perceptions of the favela, news releases of the positive improvements in infrastructure, housing, sanitation, environment, and access to gyms for use by the local community should be featured. The pacification of the favelas should continue more aggressively to favela all over the city as opposed to mainly focusing on area most frequented by tourists. It would also be advisable to capitalize on the positive images such as interesting destinations to visit, natural parks, abundant wildlife, beautiful beaches, variety of music and dance, scenic beauty, friendly people, nightlife, adventure and cultural opportunities as demonstrated in recent research by Rezende-Parker et al. [9].

\section{RESULTS OF SERVICE LEARNING EXPERIENCE}

A second part of this research explored student perceptions of their participation in a service learning project on the public image of Rio favelas post 2014 World Cup and pre-2016 Olympics. When asked why they enrolled in the course, students said they were interested in travel and tourism management whereas only two students responded that they needed a three credit class that fit into their schedule. Most of the students said it was a required course; they were interested and needed to have a city competency service learning course.

The students characterized their experience collecting surveys as challenging. Most $(88.9 \%, \mathrm{n}=24)$ indicated that it was difficult to get people to be willing to take time to respond to the survey and $44.4 \%(n=12)$ said that they had to be creative in getting people to respond. Students also suggested the data collection should not be at busy subway stations where people are in a hurry, but rather at locations where there is a long cue and wait time that would increase the likelihood that potential respondents would be willing to participate in the study. Of the students responding, 60\% $(\mathrm{n}=17)$ had participated in taking surveys prior to this assignment. Before taking this course, $53.6 \%(\mathrm{n}=15)$ of the students did not know anything about favelas. Of those who did know about favelas $(46.4 \%, n=13)$, their comments were primarily negative with an emphasis on danger, over population and poverty. This is consistent with the most common descriptors of the general NYC population survey. Some of the student reflections about favelas were:

"I had a tour of Vidigal (favela) and learned that favelas were dangerous and populated with poor people, but they were also very tight communities socially". "The residents are poor and need help".

"They are crowded neighborhood on the hills of Brazil".

"Favelas are overcrowded, dangerous and have a bad reputation".

"Favela residents are being threatened by new development in Brazil with World Cup/Olympics".

"My impression is that favelas are just poor areas. I saw this in a movie". 


\section{CONCLUSIONS OF SERVICE LEARNING EXPERIENCE}

Through this service learning assignment, students: 1) gained personal insight into the social issues presented by the favelas; 2) applied their communication and critical thinking skills in interviewing people; and 3) developed an understanding of social issues as they relate to sustainable tourism development which is consistent with the goals of service learning [23], [24]. The student reflections demonstrated that the students had learned about global social issues such as poverty and its impact on destination image and tourism. Not only did they learn by interviewing people, they also demonstrated critical thinking skills by suggesting that the method for collection survey data should be modified. Almost $86 \%(85.7 \%$, $\mathrm{n}=24$ ) agreed that the class assignment contributed to their understanding of the favelas. In addition, the students reported that the overall perception of the people they interviewed about the favelas was negative $(75 \%, \mathrm{n}=21)$. The students felt there was a connection between tourism and the favelas $(71 \%, \mathrm{n}=20) .100 \%$ of the students agreed that through this assignment, they were able to develop an understanding of their personal commitments and obligations to understand the impact of social issues on society.

\section{RECOMMENDATIONS OF SERVICE LEARNING EXPERIENCE}

Based on the results of the student survey, it is clear that hands-on projects support student learning about social issues. In this case, it was social issues and tourism in Brazil. This research demonstrated and supported the premise that the service learning project of interviewing the public regarding their perceptions of the favelas enhanced the student learning experience that helped them gain a better understanding of the favela communities [21]. Hands on projects require that students [21] understand the concepts at a different level because they are, in fact, explaining a concept to another person; listening to various opinions of the respondents and having discussions that challenges their knowledge. The survey project was a learning experience included in the course. Student reflections connected this service to a non-profit agency and learning. It is recommended that more service learning courses integrating community service with instruction and student reflection be introduced into university curriculum and become the standard as opposed to the unique.

\section{ACKNOWLEDGEMENTS}

We would like to acknowledge the contributions of the Pace University, Tourism Management Course in Fall 2016 and Catalytic Communities' invitation to participate in this research project. A special thanks to Adnan Dhiyan and Ashutosh Palriwala, graduate assistants and MBA students at Lubin School of Business Graduate Program.

\section{REFERENCES}

[1] Lonely Planet, History of Rio de Janeiro. www.lonelyplanet.com/brazil/rio-dejaneiro/history. Accessed on: 30 Jun. 2016.

[2] Williamson, T., Catalytic Communities. http://catcomm.org/perceptions/. Accessed on: 30 Jun. 2016.

[3] Mello, J., Forming a non-governmental organization in Brazil. The Brazil Business. http://thebrazilbusiness.com/article/forming-a-non-governmental-organization-inbrazil, 2012.

[4] Hurrell, F., Rio favela population largest in Brazil. The Rio Times, 27 Oct. 2015. http://riotimesonline.com/brazil-news/rio-politics/rios-favela-population-largest-inbrazil/.

[5] Life in favela of Rochina, Rio de Janeiro, 2015. http://lifeinrocinha.blogspot.com/ 2011/03/life-in-favela-pt2.html. Accessed on: 30 Jun. 2016. 
[6] Massimo, C., What government? In Rio's slums, drug gangs are the government. Wilson Quarterly. http://wilsonquarterly.com/stories/what-government-in-rios-slumsdrug-gangs-are-the-government/, 2012.

[7] Freeman, J., Raising the flag over Rio de Janeiro's favelas: Citizenship and social control in the Olympic City. Journal of Latin American Geography, 13(1), pp. 7-38, 2014.

[8] Oosterbaan, S. \& van Wijk, J., Pacifying and integrating the favelas of Rio de Janeiro: An evaluation of the impact of the UPP program on favela residents. International Journal of Comparison and Applied Criminal Justice, 3(3), pp. 179-198, 2014.

[9] Rezende-Parker, A.M., Morrison, A.M. \& Ismail, J.A., Dazed and confused? An exploratory of the image of Brazil as a travel destination. Journal of Vacation Marketing, 9(3), pp. 243-259, 2003.

[10] Ma, B., A trip into the controversy: A study of slum tourism travel motivations. Undergraduate Humanities Forum 2009-2010: Connections. http://repository.upenn.edu/uhf_2010/12. Accessed on: 30 Jun. 2016.

[11] Rezende, R., Turismo comunitário e favela-tour como expressões das novas dinâmicas do consumo turístico. Revista Turismo em Análise, Brasil, 25(2), pp. 354-372, 2014.

[12] Baloglu, S. \& McCleary, K.W., A model of destination image formation. Annals of Tourism Research, 26(1), pp. 868-899, 1999.

[13] Crompton, J.L., An assessment of the image of Mexico as a vacation destination and the influence of geographical location upon that image. Journal of Travel Research, 17(4), pp. 18-23, 1979.

[14] Gartner, W.C., Tourism image: Attribute measurement of state tourism products using multidimensional techniques. Journal of Travel Research, 28(2), pp. 16-20, 1989.

[15] Echtner, C.M. \& Ritchie, J.R.B., The measurement of destination image: An empirical assessment. Journal of Travel Research, 31(4), pp. 3-13, 1993.

[16] Tasci, A.D.A., Gartner, W.C. \& Cavusgil, S.T., Conceputalization and operationalization of destination image. Journal of Hospitality \& Tourism Research, 31(2), pp.194-223, 2007.

[17] King, C., Chen, N. \& Funk, D.C., Exploring destination image decay: A study of sports tourists' destination image change after event participation. Journal of Hospitality \& Tourism Research, 39(1), pp. 3-31, 2015.

[18] Catalytic Communities, Favelas in the media: How the global narrative on favelas changed during Rio's mega-event years. http://catcomm.org/media-analysis-2016/. Accessed on: 23 May 2017.

[19] Kenworthy-U'Ren, A.L., A decade of service-learning. A review of the field ten years after JOBE's seminal special issue. Journal of Business Ethics, 81(4), pp. 811-822, 2008.

[20] Petkus, E., A theoretical and practical framework for service-learning in marketing: Kolb's experimental learning cycle. Journal of Marketing Education, 22(1), pp. 64 70, 2000.

[21] National Service Learning Clearing House, https://gsn.nylc.org/clearinghouse. Accessed on: 30 Jun. 2016.

[22] McCarthy, A.M. \& Tucker, M.L., Encouraging community service through service learning. Journal of Management Education, 26(6), pp. 629-647, 2002.

[23] Kolenko, T.A., Porter, G., Wheatley, W. \& Colby, M., A critique of service learning projects in management education: Pedagogical foundations, barriers, and guidelines, Community involvement and service learning student projects. Journal of Business Ethics, 15(1), pp. 133-142, 1996. 
[24] Gray, M.J., Ondaatje, E.H., Fricker Jr, R.D. \& Geschwind, S.A., Assessing servicelearning: Results from a survey of "Learn and Serve America, Higher Education". Change: The Magazine of Higher Learning, 32(2), pp. 30-39, 2000.

[25] Campus Compact, www.compact.org. Accessed on: 23 Jun. 2015. 